University of Nebraska - Lincoln

DigitalCommons@University of Nebraska - Lincoln

U.S. Environmental Protection Agency Papers

U.S. Environmental Protection Agency

2005

U.S. EPA's IRIS assessment of 2-butoxyethanol: the relationship of noncancer to cancer effects

J. S. Gift

U.S.EPA, gift.jeff@epa.gov

Follow this and additional works at: https://digitalcommons.unl.edu/usepapapers

Gift, J. S., "U.S. EPA's IRIS assessment of 2-butoxyethanol: the relationship of noncancer to cancer effects" (2005). U.S. Environmental Protection Agency Papers. 168.

https://digitalcommons.unl.edu/usepapapers/168

This Article is brought to you for free and open access by the U.S. Environmental Protection Agency at DigitalCommons@University of Nebraska - Lincoln. It has been accepted for inclusion in U.S. Environmental Protection Agency Papers by an authorized administrator of DigitalCommons@University of Nebraska - Lincoln. 


\title{
U.S. EPA's IRIS assessment of 2-butoxyethanol: the relationship of noncancer to cancer effects
}

\author{
J.S. Gift* \\ U.S. EPA, National Center for Environment Assessment (MD-B243-01), Research Triangle Park, NC 27711, USA
}

Received 8 May 2003; accepted 14 August 2003

Available online 7 December 2004

\begin{abstract}
U.S. EPA's integrated risk information system (IRIS) assessment of 2-butoxyethanol (EGBE) indicates that the human carcinogenic potential of EGBE cannot be determined at this time, but that "suggestive evidence" for cancer exists from laboratory animal studies (hemangiosarcoma of the liver in male mice and forestomach squamous cell papilloma or carcinoma in female mice [National Toxicology Program (NTP), 2000a. Toxicology and carcinogenesis studies of 2-butoxyethanol (CAS no. 11176-2) in F344/N rats and B6C3F1 mice (inhalation studies). National Toxicology Program Technical Report Series No. 484. U.S. Department of Health and Human Services, National Institutes of Health, Washington, DC]). Since the last EGBE IRIS assessment, a number of studies have provided evidence that the carcinogenic effects observed in mice are nonlinear in their mode of action and may be dependent on threshold events such as EGBE-induced hemolytic effects. EPA is in the process of considering several questions relating to this issue. First, can a plausible mode of action be determined for the two types of tumors observed in mice? Second, are the mechanisms involved applicable to humans? If so, should the mode of action be considered to result in a linear or nonlinear dose-response? These questions will be addressed within the context of the agency's new cancer guidelines and with regard to how the answers might affect a revised IRIS assessment for EGBE.
\end{abstract}

(C) 2004 Elsevier Ireland Ltd. All rights reserved.

Keywords: 2-Butoxyethanol; EGBE

\section{Background}

Ethylene glycol butyl ether (EGBE; 2butoxyethanol) is a chemical solvent widely used in formulating cleaning products and protective coatings. It has been studied extensively in oral, dermal, and

* Tel.: +1 919541 4282; fax: +1 9195411818.

E-mail address: gift.jeff@epa.gov. inhalation toxicological studies of several species (U.S. EPA, 1999a); and hemolysis is consistently observed as the primary effect of EGBE exposure. The 2-butoxyacetic acid (BAA) metabolite of EGBE has been shown to be the causative agent in this hemolysis. In vitro studies have shown that the red blood cells of humans are less sensitive to the hemolytic effects of EGBE/BAA than are those of typical laboratory species (Ghanayem, 1989; Udden, 2002). In addition,

0378-4274/\$ - see front matter (C) 2004 Elsevier Ireland Ltd. All rights reserved. doi:10.1016/j.toxlet.2003.08.014

This article is a U.S. government work, and is not subject to copyright in the United States. 
no hemolysis has been observed in controlled laboratory acute inhalation exposures of human volunteers to up to $195 \mathrm{ppm}$ EGBE (Carpenter et al., 1956). Effects in humans from long-term exposure to EGBE have not been studied (U.S. EPA, 1999a). However, long-term exposure studies of rats and mice have reported both hemolytic and carcinogenic effects (NTP, 2000a), raising concern that EGBE might be a human carcinogen.

Based on the available data and using the 1996 proposed guidelines for carcinogen risk assessment (U.S. EPA, 1996), EPA reported in its 1999 IRIS assessment (U.S. EPA, 1999a) that the human carcinogenicity of EGBE cannot be determined at this time, but that suggestive evidence (i.e., slight increases in liver hemangiosarcomas in male mice and forestomach tumors in female mice) exists from rodent studies. Under the existing EPA guidelines (U.S. EPA, 1986), EGBE was judged to be a "possible human carcinogen". A quantitative assessment of EGBE's cancer potency was not derived due to uncertainties associated with the human relevance of the mode of action for the formation of the tumors that were observed in laboratory animals following EGBE exposure.

Since the completion of the EGBE IRIS assessment (U.S. EPA, 1999a), several studies have been performed to investigate possible carcinogenic mechanisms for the development of liver hemangiosarcomas in male mice (Kamendulis et al., 1999; Siesky et al., 2001, 2002; Park et al., 2002a,b) and forestomach tumors in female mice (Bennett, 2000; Poet et al., 2003; Corley et al., 1999; Green, 2000; Poet et al., 2002) following exposure to EGBE. This paper discusses the mode of action for and human relevance of carcinogenic effects observed in mice following EGBE exposure in light of these new studies, with particular focus on liver effects observed in male mice because of their higher potential relevance to humans.

\section{Mode of action for tumors observed in EGBE-exposed animals}

Although results of available in vitro genotoxicity assays have been somewhat mixed, recent reviews (Commonwealth of Australia, 1996; Elliot and Ashby, 1997; U.S. EPA, 1999a; NTP, 2000a) agree that EGBE is not likely to be genotoxic in vivo. Based on chemi- cal structure, EGBE itself does not resemble any known chemical carcinogens and is not expected to have electrophilic or DNA reactive activity. However, as is extensively discussed in the agency's draft cancer guidelines (U.S. EPA, 1999b), chemicals can have a range of key influences as initiators or promoters of the complex carcinogenic process. With this in mind, EGBE's role in the formation of female mouse forestomach and male mouse liver tumors observed following 2 years of inhalation exposure (NTP, 2000a) were assessed. These evaluations were done using the framework for evaluating mode of action that is outlined in the U.S. EPA (1999b) draft cancer guidelines.

\subsection{Forestomach papillomas and carcinoma observed in female mice}

\subsubsection{Background}

Table 1 summarizes the data for key tumor types that have been observed in female mice (NTP, 2000a). At the $250 \mathrm{ppm}$ exposure level, the $10 \%$ incidence of squamous papilloma and $12 \%$ incidence of squamous cell papilloma or carcinoma (combined) were significantly increased over study controls ( $0 \%$ incidence). The historical range of forestomach tumors in control mice from NTP inhalation carcinogenicity studies averaged $0.3 \%$ and ranged from $0 \%$ to $2 \%$ for carcinomas and averaged $1.6 \%$ and ranged from $0 \%$ to $6 \%$ for papillomas (Haseman et al., 1998). NTP (2000a,b) reports that $8 \%$ is the highest incidence of forestomach neoplasms that has been observed in any contemporary historical control group. NTP (2000a) did not observe significant increases in forestomach papillomas and carcinomas at other exposure levels in female mice, nor at any exposure level in male mice or either sex of rats.

\subsubsection{Dosimetry}

In addition to EGBE, forestomach hyperplasia in male and female mice has been associated with vapor inhalation exposure to acetonitrile (NTP, 1996), 1,3-butadiene (NTP, 1993a) and chloroprene (NTP, $1998 \mathrm{a}, \mathrm{b})$. Given that the rodent forestomach is known to be poorly vascularized and that the cells of the epithelium, especially the more superficial squamous cells, are separated from capillaries by substantial diffusion distances (Bueld and Netter, 1993), it seems more likely that these compounds or their metabolites are delivered to the forestomach by ingestion rather than system- 
Table 1

Key tumors observed in female mice (NTP, 2000a)

\begin{tabular}{|c|c|c|c|c|}
\hline & Control & $62.5 \mathrm{ppm}$ & $125 \mathrm{ppm}$ & $250 \mathrm{ppm}$ \\
\hline Squamous cell papilloma-forestomach & $0 / 50$ & $1 / 50$ & $2 / 50$ & $5 / 50$ \\
\hline Overall rate $(\%)$ & 0 & 2 & 4 & 10 \\
\hline Rate adjusted for intercurrent mortality $(\%)^{\mathrm{a}}$ & 0 & 2.4 & 4.8 & 11.2 \\
\hline First incidence (days) & NA & 731 & 731 & 582 \\
\hline Squamous cell papilloma or carcinoma-forestomach & $0 / 50$ & $1 / 50$ & $2 / 50$ & $6 / 50$ \\
\hline Overall rate $(\%)$ & 0 & 2 & 4 & 12 \\
\hline Rate adjusted for intercurrent mortality (\%) & 0 & 2.4 & 4.8 & 13.4 \\
\hline First incidence (days) & NA & 731 & 731 & 582 \\
\hline
\end{tabular}

a Poly-3 test estimate taken from NTP (2000a) technical report series 484 .

ically. In the case of EGBE, it has been shown that upon iv administration, EGBE metabolites can rapidly accumulate in salivary secretions which are swallowed (Bennett, 2000) and that ip injection causes forestomach lesions similar to those observed in gavage and inhalation studies (Corley, 1999). Corley et al. (1999) have suggested that the minimal lesions observed following sc administration of similar doses is an indication of the importance of first-pass liver metabolism. If first-pass metabolism is important, however, an explanation must be provided for why forestomach hyperplasia was not reported in the subchronic drinking water study at comparable $\mathrm{mg} / \mathrm{kg} /$ day doses (NTP, 1993b). It is possible that the formation of lesions requires persistent and high EGBE metabolite (BAA) concentrations in the forestomach that are attainable following gavage (Ghanayem et al., 1987a), inhalation (Green, 2000), and ip exposures (Poet et al., 2002), but are not attainable from drinking water exposure.

Because systemic circulation alone is not likely to be responsible for the occurrence of forestomach lesions in these inhalation studies, other sources of ingested EGBE or EGBE metabolites must be considered. Researchers have established the following: (a) a small amount $(9-10 \mathrm{mg} / \mathrm{kg})$ of neat EGBE was likely available for oral consumption via daily grooming following the NTP inhalation exposures (Corley et al., 1999; Green, 2000); (b) the forestomachs of rodents are known to sequester EGBE for an extended period of time after gavage exposures (Ghanayem et al., 1987a); (c) direct, neat exposure to EGBE, without first-pass liver metabolism, can cause forestomach lesions similar to those observed by the NTP (2000a,b) following inhalation exposure (Corley et al.,
1999); (d) EGBE causes cytotoxicity through its 2BAA metabolite (Udden, 2000); (e) concentration is a more critical factor than duration with respect to BAA's ability to cause cell lysis (U.S. EPA, 1999c). ${ }^{1}$ These findings suggest that active irritant metabolites of EGBE may be produced locally in the forestomach. It is also possible that tissues of the upper respiratory tract produce metabolites of EGBE, ${ }^{2}$ which are transferred to secretions and swallowed. It is more plausible that some combination of grooming followed by local metabolism, and the swallowing of metabolized respiratory tract secretions, followed by chronic irritation, is responsible for the formation of these lesions.

\subsubsection{Pathology}

The high concentrations of EGBE and its BAA metabolite sequestered in the forestomach through prolonged exposure are assumed to be the cause of chronic irritation and the more serious damage observed in the forestomach lining of female mice. Incidences of ulcers consisting of a lesion in the forestomach wall that penetrated the full thickness of the forestomach epithelium were significantly increased in all exposed groups of females. NTP (2000a) suggests that EGBE exposure caused inflammatory and hyperplastic effects in the forestomach and that "the neoplasia [papillomas and one carcinoma] was associated with a continuation of the injury/degeneration process".

\footnotetext{
${ }^{1}$ This is why Cmax and not AUC was used as an internal dose metric for animal to human adjustments performed in the establishment of the inhalation RfC.

2 The upper respiratory tract of rodents, including the olfactory epithelium, has been found to contain significant metabolic capacity with respect to acrylates and other compounds (Mattes and Mattes, 1992; Green, 1996; Bogdanffy et al., 1987).
} 
No clear explanation has been presented in the literature for the lack of sensitivity of male mice to forestomach neoplasms by the inhalation exposure route (Cantox Environmental Inc., 2000). However, female mice of the NTP (2000a) study were clearly more susceptible to inflammation and hyperplasia than males at similar exposure levels; and it is likely that these tumors occurred via indirect mechanisms involving chronic tissue injury. Forestomach effects, particularly tumor observations in females, were preceded or accompanied by marked signs of irritation, including hyperplasia and ulceration. The female mice of this 2-year inhalation study experienced hyperplasia of the epithelium in the forestomach at all exposure levels $(54 \%$ at $62.5 \mathrm{ppm}$, $86 \%$ at $125 \mathrm{ppm}$, and $88 \%$ at $250 \mathrm{ppm}$ ), as did female mice in the 14-week inhalation study (NTP, 2000a). No similar evidence of hyperplasia was noted in mice or rats in an earlier 13-week drinking water study (NTP, 1993a,b,c).

\subsection{Liver hemangiosarcomas in male mice}

\subsubsection{Background}

Table 2 summarizes the data for key tumor types observed in male mice exposed to EGBE by inhalation in studies conducted by NTP (2000a). Particular focus has been placed on hemangiosarcomas of the liver as this is the only organ site with an increased incidence of this tumor type. However, combination of this cardiovascular system (vascular endothelium) tumor type across organ systems is also considered potentially relevant for quantifying cancer risk. The combined incidence of hemangiomas and hemangiosarcomas is considered potentially relevant although the suggestion that hemangiomas represent a first stage in the development of hemangiosarcomas is not universally accepted, even for chemicals that are known to act by a direct genotoxic mechanism (McConnell et al., 1986). Establishment of the mode of action for the development of these tumors in mice would be important for any quantitative assessment of potency (i.e., selecting a linear or nonlinear dose-response modeling method) and any qualitative determination of human relevance.

\section{Postulated mode of action}

In the EGBE IRIS assessment (U.S. EPA, 1999a), EPA determined that the information available did not allow for a definitive statement regarding the mode of action for the increase in the incidence of hemangiosarcomas in the livers of male mice. Since that time, considerable research has been completed in this area, and several scientists have postulated a hemolysismediated mode of action for the formation of these tumors (Klaunig et al., 1998; Kamendulis et al., 1999; Xue et al., 1999; Siesky et al., 2001; Foster, 2000; Boatman, 2000; Park et al., 2002a,b; Klaunig, 2002). This section will examine these new research findings and proposals in light of the agency's recently published draft cancer guidelines (U.S. EPA, 1999b).

In general, the current draft of the guidelines (U.S. EPA, 1999b) requires discussion of the proposed mode of action, the strength of its supporting database,

Table 2

Key tumors observed in male mice (NTP, 2000a)

\begin{tabular}{|c|c|c|c|c|}
\hline & Control & $62.5 \mathrm{ppm}$ & $125 \mathrm{ppm}$ & $250 \mathrm{ppm}$ \\
\hline Hemangiosarcomas-all organs & $1 / 50$ & $1 / 50$ & $2 / 50$ & $5 / 50$ \\
\hline Overall rate $(\%)$ & 2 & 2 & 4 & 10 \\
\hline Rate adjusted for intercurrent mortality $(\%)^{\mathrm{a}}$ & 2.2 & 2.1 & 5.0 & 12.4 \\
\hline First incidence (days) & 729 & 670 & 704 & 454 \\
\hline Hemangiosarcomas-liver only & $0 / 50$ & $1 / 50$ & $2 / 49$ & $4 / 49$ \\
\hline Overall rate $(\%)$ & 0 & 2 & 4 & 8 \\
\hline Rate adjusted for intercurrent mortality (\%) & 0 & 2.1 & 5.0 & 10 \\
\hline First incidence (days) & NA & 670 & 704 & 454 \\
\hline Hemangiosarcomas/hemangiomas_-all organs & $1 / 50$ & $1 / 50$ & $4 / 50$ & $5 / 50$ \\
\hline Overall rate $(\%)$ & 2 & 2 & 8 & 10 \\
\hline Rate adjusted for intercurrent mortality (\%) & 2.2 & 2.1 & 10 & 12.4 \\
\hline First incidence (days) & NA & 670 & 704 & 454 \\
\hline
\end{tabular}

a Poly-3 test estimate taken from NTP (2000a) technical report series 484 . 


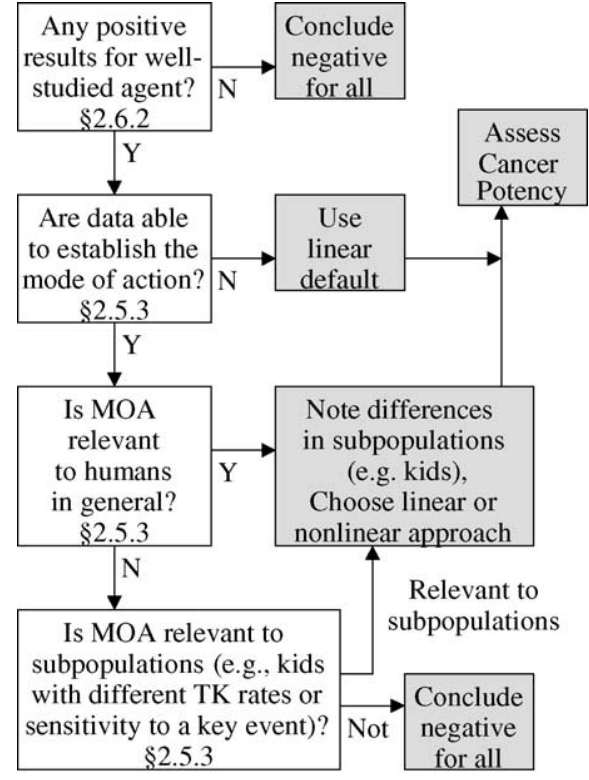

Fig. 1. Framework of EPA guidelines for risk assessment [numbers in the boxes refer to sections in the draft cancer guidelines (U.S. EPA, 1999b)].

whether it is believed to be operative in humans, and whether any human subpopulation is apt to "qualitatively respond to the mode of action differently than the general population". The framework for this approach is illustrated in Fig. 1 and is applied here to assess the mode of action for EGBE-induced liver hemangiosarcomas in male mice and its relevance to humans. The following is a six-step summary of the mode of action that has been proposed.

1. EGBE is metabolized via alcohol dehydrogenase to 2-butoxyacetaldehyde which is oxidized via aldehyde dehydrogenase to 2-butoxyacetic acid (BAA).

2. BAA causes hemolysis of red blood cells.

3. Hemosiderin derived from the excess hemoglobin is taken up by and stored in phagocytic (e.g., Kupffer) cells of the spleen and liver.

4. Oxidative damage and increased synthesis of endothelial DNA are initiated by one or more of the following events:

- Generation of reactive oxygen species (ROS) from iron within Kupffer cells (Siesky et al., 2002; Park et al., 2002a,b).
- Generation of ROS from excess iron that directly enters sinusoidal endothelial cells (Foster, 2000). ${ }^{3}$

- Activation of Kupffer cells to produce cytokines/growth factors which suppress apoptosis and promote cell proliferation (Siesky et al., 2002).

5. Chronically increased DNA synthesis and damage leads to endothelial DNA mutations.

6. Potentiation and promotion of neoplastic cell populations results from accumulation of multiple endothelial DNA mutations.

\subsection{Strength, consistency, and specificity of association of tumor response with key events}

This hypothesized mode of action would suggest that the pathology of hemangiosarcoma development from EGBE exposure is nonlinear and dependent upon the level of hemolysis, the amount of iron buildup within the target cell population, and the repair capacity of that cell population. The first four key events listed above are fairly well described and documented in the EGBE literature. Steps 1 and 2, the metabolism of EGBE to BAA and the association of BAA with hemolytic effects has been clearly established in multiple in vivo and in vitro tests involving both sexes of several species, including rats and mice (U.S. EPA, 1999a).

Step 3 has been verified through the observation of hemosiderin (iron) within Kupffer cells and hepatocytes following prolonged breakdown of the red blood cells in both sexes of rats and mice exposed to EGBE (NTP, 2000a; Ghanayem and Sullivan, 1993; Ghanayem et al., 1987b,c; Krasavage, 1986; Kamendulis et al., 1999; Siesky et al., 2002). A possible indication of the importance of hemolysis to tumor formation is given by the fact that splenic hematopoietic cell proliferation in the mice with liver hemangiosarcomas was reported to be more severe (average severity grade of 3.2 for all dose groups)

\footnotetext{
${ }^{3}$ It is possible that a continued cycle of hemolysis and hemoglobin release can eventually overwhelm normal phagocytic mechanisms, causing iron to appear within cells that normally would not contain significant amounts of hemosiderin, such as the hepatocytes and sinusoidal endothelial cells. However, the necessity and extent of such buildup are not clear (see later discussion of "the relation between Kupffer cell pigmentation and the sinusoidal endothelial cells").
} 
than in mice that did not develop hemangiosarcomas (average severity grade of 2.3).

A recent gavage study (Siesky et al., 2002) of rats and mice subchronically exposed to EGBE provides support for step 4 of the proposed mechanism, the induction of oxidative damage and increased DNA synthesis within endothelial cells. However, some uncertainty remains regarding this step in the proposed mechanism. These and other investigators (Kamendulis et al., 1999; Park et al., 2002a) have indeed demonstrated the observed hepatic oxidative stress is more likely to result from EGBEinduced hemolysis and the subsequent increase in iron deposition rather than through a compound or metabolite-specific mechanism. However, Siesky et al. (2002) looked for but did not observe iron within endothelial cells, and the observed indicators of oxidative damage (increased $\mathrm{OH} 8 \mathrm{dG}$ and malondialdehyde levels) were only recorded for total liver. Thus, they did not provide evidence for a direct link between iron induced endothelial cell DNA damage and the observed increase in endothelial cell DNA synthesis. This may or may not be important. Siesky et al. (2002) and Rose et al. (1997, 1999) have suggested that increased endothelial cell DNA synthesis and oxidative damage can occur without direct iron involvement through indirect Kupffer cell activation leading to the release of cytokines and growth regulatory molecules, which contribute to the induction of endothelial DNA synthesis and damage. Given the apparent predisposition of male mouse endothelial cells to carcinogenic transformation, this may be enough to trigger mutations and tumor formation. Yet, due to the large amount of hemosiderin that was observed in Kupffer cells and the relative insensitivity of the Perl staining tests employed, it is also possible that some significant amount of iron can penetrate and have a more direct impact on endothelial cells (Ghio, 2002).

The last two key events of the proposed mode of action suggest that the extent and duration of oxidative damage and increased DNA synthesis within endothelial cells are sufficient to lead to fixed mutations and the potentiation and promotion of neoplastic cell populations. These proposed steps are not so well documented, but are consistent with evidence from other studies of chemicals that cause hemosiderin buildup in male mice. Table 3 presents the liver hemangiosar- comas incidence for all chemicals identified in NTP studies ${ }^{4}$ as causing hemosiderin pigmentation of the Kupffer cells following chronic exposure. ${ }^{5}$ None of the six chemicals found to cause Kupffer cell hemosiderin pigmentation in male or female rats following chronic exposure (any route) caused a statistically significant increase in liver hemangiosarcomas. Similarly, none of the seven chemicals found to cause hemosiderin buildup in Kupffer cells of female mice ${ }^{6}$ caused an increase in liver hemangiosarcomas. In contrast, chronic exposure to four of the seven chemicals causing Kupffer cell hemosiderin pigmentation in male mice caused significant increases in the incidence of liver hemangiosarcomas.

Male mouse sensitivity over rats and female mice may be explained by an increased sensitivity to oxidative stress (Kamendulis et al., 1999; Siesky et al., 2001) and predisposed endothelial cells. The latter is indicated by the higher historical control incidence of hemangiosarcomas in male mice (see discussion below of male versus female historical rates). The fact that mice, but not rats, experience early increases in endothelial cell DNA synthesis (Siesky et al., 2002) and a sustained hemolytic response (see discussion of temporal relationships below), would also be consistent with the apparent mouse liver specificity for this tumor.

\subsection{Temporal association}

Key steps in the proposed mode of action hemolysis-hemosiderin buildup and oxidative damage - have all been observed in subchronic or shorter duration rat and mouse studies (NTP, 2000a; Kamendulis et al., 1999; Siesky et al., 2002), well in advance of tumor formation. Increased endothelial

\footnotetext{
${ }^{4}$ Data for Table 3 were obtained via a search of NTP's post-PWG TDMS database (http://ntp-apps.niehs.nih.gov/postpwg/ webapp.open.cfm).

${ }^{5}$ Chemicals were not included if they caused pigmentation that was not believed to be hemosiderin, such as bile or porphyrin pigmentation, and was not observed in the Kupffer cells.

${ }^{6}$ Pentachlorophenol (Dowicide and Technical grade) caused a statistically significant increase in liver hemangiosarcomas, but the liver pigmentation observed was not identified as hemosiderin and was not in the Kupffer cells. Since pentachlorophenol is genotoxic and causes precursor lesions of the liver similar to those observed following exposure to vinyl chloride, it is likely that it is acting by a different mode of action than that which is proposed for EGBE.
} 
Table 3

Incidence of liver hemangiosarcomas in NTP chemicals causing increased hemosiderin in Kupffer cells

\begin{tabular}{|c|c|c|c|c|}
\hline Chemical—NTP TR\# & Hemosiderin (chronic study) & 14-Week study & Hemangiosarcoma & Route \\
\hline \multicolumn{5}{|l|}{ Male rats (F344) } \\
\hline 2-Butoxyethanol (EGBE)—TR-484 & $23 / 50,30 / 50,34 / 50,42 / 50$ & Yes & $0 / 50,0 / 50,1 / 50,0 / 50$ & Inh. \\
\hline Butyl benzyl phthalate-TR-458 & $2 / 60,1 / 60,6 / 60,6 / 60$ & No & None reported & Feed \\
\hline p-Chloroaniline hydrochloride-TR-351 & $1 / 49,0 / 50,0 / 50,26 / 50$ & No & Not reported & Gavage \\
\hline$o$-Nitroanisole-TR-416 & $0 / 20,1 / 20,18 / 20$ & No & None reported & Feed \\
\hline Pyridine-TR-470 & $4 / 50,11 / 50,20 / 50,25 / 50$ & No & None reported & Water \\
\hline \multicolumn{5}{|l|}{ Female rats (F344) } \\
\hline 2-Butoxyethanol (EGBE)-TR-484 & $15 / 50,19 / 50,36 / 50,47 / 50$ & Yes & $0 / 50,0 / 50,0 / 50,0 / 50$ & Inh. \\
\hline Butyl benzyl phthalate-TR-458 & $4 / 60,1 / 60,6 / 60,10 / 60$ & No & None reported & Feed \\
\hline CI pigment red 3-TR-407 & $0 / 50,3 / 50,14 / 50,41 / 50$ & No & None reported & Feed \\
\hline$o$-Nitroanisole-TR-416 & $8 / 20,2 / 20,20 / 20$ & No & None reported & Feed \\
\hline Pyridine-TR-470 & $6 / 50,2 / 50,6 / 50,17 / 50$ & No & None reported & Water \\
\hline \multicolumn{5}{|l|}{ Male mice (B6C3F1) } \\
\hline 2-Butoxyethanol (EGBE) & $0 / 50,0 / 50,8 / 50,30 / 50$ & Yes & $0 / 50,1 / 50,2 / 50,4 / 50$ & Inh. \\
\hline p-Chloroaniline hydrochloride-TR-351 & $0 / 50,0 / 49,0 / 50,50 / 50$ & Yes & $2 / 50,2 / 49,1 / 50,6 / 50$ & Gavage \\
\hline$p$-Nitroaniline-TR-418 & $1 / 50,1 / 50,8 / 50,50 / 50$ & Yes & $0 / 50,1 / 50,2 / 50,4 / 50$ & Gavage \\
\hline Pentachloroanisole-TR-414 & $1 / 50,50 / 50,50 / 50^{\mathrm{a}}$ & Yes & $2 / 50,8 / 50,10 / 50$ & Gavage \\
\hline CI pigment red 3-TR-407 & $0 / 50,5 / 50,30 / 50,41 / 50$ & No & $0 / 50,1 / 50,1 / 50,0 / 50$ & Feed \\
\hline 2,4-Diaminophenol dihydrochloride-TR-401 & $0 / 50,44 / 50,47 / 50$ & No & $1 / 50,0 / 50,1 / 50$ & Gavage \\
\hline$o$-Nitroanisole-TR-416 & $0 / 50,0 / 50,3 / 50,16 / 50$ & No & $2 / 50,2 / 50,1 / 50,0 / 50$ & Feed \\
\hline \multicolumn{5}{|l|}{ Female mice (B6C3F1) } \\
\hline 2-Butoxyethanol (EGBE)—TR-484 & $0 / 50,5 / 50,25 / 50,44 / 50$ & Yes & $0 / 50,0 / 50,1 / 50,0 / 50$ & Inh. \\
\hline p-Chloroaniline hydrochloride-TR-351 & $0 / 50,0 / 50,1 / 50,46 / 50$ & Yes & $1 / 50,0 / 50,0 / 50,1 / 50$ & Gavage \\
\hline CI pigment red 3-TR-407 & $2 / 50,1 / 50,1 / 50,29 / 50$ & No & $0 / 50,1 / 50,0 / 50,0 / 50$ & Feed \\
\hline 2,4-Diaminophenol dihydrochloride-TR-401 & $0 / 50,31 / 50,50 / 50$ & No & $0 / 50,0 / 50,0 / 50$ & Gavage \\
\hline Methyleugenol-TR-491 & $0 / 50,11 / 50,24 / 50,19 / 50^{\mathrm{b}}$ & No & $0 / 50,1 / 50,0 / 50,0 / 50$ & Gavage \\
\hline$p$-Nitroaniline-TR-418 & $1 / 50,1 / 50,4 / 50,39 / 50$ & No & $1 / 50,1 / 50,0 / 50,0 / 50$ & Gavage \\
\hline Pentachloroanisole-TR-414 & $0 / 50,37 / 50,48 / 50^{1}$ & Yes & $0 / 50,0 / 50,1 / 50$ & Gavage \\
\hline
\end{tabular}

a Authors reported (NTP, 1993c) Kupffer cells with yellow-brown granules of undetermined identity. "Appropriate staining procedures" did not reveal iron, bile or PAS-positive materials in these granules. The authors suggested that they may consist of one or more porphyrins because cellular porphyrins are known to be produced from exposure to other chlorinated hydrocarbons. However, the possibility that the pigmentation may have consisted of hemosiderin "was not entirely eliminated".

b Pigment identified as hemosiderin, but not explicitly reported in Kupffer Cells (NTP, 2000c).

cell DNA synthesis was observed at exposure days 7 and 14 in mice, but not rats. This may be an indication of the need for very early lifestage endothelial cell damage.

The importance of early lifestage and sustained endothelial cell damage may also be given by the fact that of the seven chemicals found to increase hemosiderin levels in male mice (Table 3), only the four chemicals that did so within 14 weeks (EGBE, $p$ chloroaniline, $p$-nitroaniline, and pentachloroanisole ${ }^{7}$ )

\footnotetext{
${ }^{7}$ It is not clear that the "yellow-brown granules" found in Kupffer cells of rats and mice exposed to pentachloroanisole contained hemosiderin (NTP, 1993c). "Appropriate staining procedures" did not reveal iron, and there was no evidence of hemolytic activity. The
}

were shown to induce hemangiosarcomas. In studies of the other three chemicals, hemosiderin buildup was not observed until the end of the 2-year study. Early buildup of hemosiderin (combined with early increases in endothelial cell DNA synthesis) would result in a longer exposure of cells to oxidative damage via irongenerated radicals (step 4) which would be consistent with a mechanism involving a continuing cycle of damage and repair and accumulation of DNA mutations (steps 5 and 6). Thus, it is possible that the three chemicals did not induce liver hemangiosarcomas because of

authors suggested that they may consist of one or more porphyrins, but none were identified. Thus, the possibility that the pigmentation consisted of hemosiderin "was not entirely eliminated". 
temporal differences in their initiation of hemosiderin buildup.

A possible explanation for the lack of hemangiosarcomas in rats may be that mice experience a more sustained hemolytic response to EGBE than rats. Mice experienced an increase in liver and splenic hematopoietic cell proliferation throughout the 2-year NTP (2000a) study while rats did not show evidence of a sustained hemolytic response, ${ }^{8}$ and do not develop hemangiosarcomas.

\subsection{Dose-response relationships}

As can be seen from the EGBE-specific data in Table 3, the liver hemangiosarcoma response in the four male mouse studies for which subchronic hemosiderin buildup was observed appears to be dose-related. Endpoints describing alleged precursor effects, splenic hematopoietic cell proliferation, and liver hemosiderin accumulation are coincident and dose-related (U.S. EPA, 1999a).

\subsection{Biological plausibility and coherence of the database}

Oxidative damage is increasingly recognized as playing an important role in the pathogenesis of several diseases, including carcinogenesis and cardiovascular disease (Lesgards et al., 2002). In support of the proposed hypothesis, increased reactive oxidative stress is known to accompany large amounts of iron released during hemolysis (Ziouzenkova et al., 1999). If EGBE causes oxidative stress by this mode of action one would expect to observe the production of protein and DNA damage following EGBE exposure, some of which will occur via the production of adducts of OH8dG (Yamaguchi et al., 1996; Wang et al., 1995; Houglum et al., 1997). This was verified by both Kamendulis et al. (1999) and Siesky et al. (2001), who measured a dose-dependent increase in levels of OH8dG and MDA and a decrease in Vitamin E levels in

\footnotetext{
8 Though rats are initially more sensitive to hemolysis than mice and were used to derive the EPA RfC for EGBE, they tend to compensate for the effects of EGBE after a few months. This increased tolerance is documented in the IRIS file for EGBE and is evidenced by a lack of induction of splenic hematopoiesis at the end of the 2-year NTP (2000a) study.
}

the livers of mice acutely and subchronically exposed to EGBE.

Liver hemangiosarcomas develop from the endothelial cell component of the vascular sinusoidal cells of the liver (Frith and Ward, 1979). The fact that iron (hemosiderin), which is known to accumulate in cells of rodent livers following EGBE exposure, can produce hydroxyl radicals in combination with oxidative by-products via the Fenton reaction (Kamendulis et al., 1999) has led several scientists (Xue et al., 1999; Siesky et al., 2001; Foster, 2000; Boatman, 2000; Kamendulis et al., 1999; Bachowski et al., 1997; Klaunig et al., $1995)$ to suggest that male mouse liver hemangiosarcomas result from increased oxygen radical damage and an associated increase in endothelial cell DNA synthesis caused by excess iron from hemolysis. The damaging effects of iron to liver sinusoidal cells in mice exposed to a combination of lindane and iron (Junge et al., 2001) lends support to this hypothesis. Additional support for this hypothesis is found in the fact that endothelial cells do appear to be more susceptible than other cells (e.g., hepatocytes or Kupffer cells) to oxidative stress (DeLeve, 1998; Spolarics, 1999).

While largely supported by recent laboratory research, several questions remain concerning the postulated mode of action. The questions outlined below may be resolvable through further research. However, they may indicate, as NTP (2000a) suggests, that the accumulation of hemosiderin and related oxidative stress alone are not the sole cause of liver neoplasms in male mice:

- Is the severity and incidence of observed Kupffer cell pigmentation at terminal sacrifice sufficient to suggest that oxidative stress from hemosiderin buildup in these cells is solely responsible for the increased incidence of liver hemangiosarcoma in the male mouse? NTP (2000a) has suggested that hemosiderin buildup is not related to the formation of liver hemangiosarcomas because Kupffer cell pigmentation was only of minimal severity and only observed in three of the four high-dose male mice that developed this tumor. However, given the apparent susceptibility of male mouse endothelial cells, it is reasonable to hypothesize that the reported minimal pigmentation observed over such a large percentage of high-dose animals (61\% in the $250 \mathrm{ppm}$ exposure group versus $0 \%$ in controls) could have caused the marginal 
increase in hemangiosarcomas reported for this dose group (8\% versus $0 \%$ in controls, with a $2.5 \%$ mean historical background rate). Additionally, the fact that Kupffer cell pigmentation was not reported for one of the four mice with liver hemangiosarcomas does not preclude the proposed mechanism because (a) the Perls Prussian blue stain for iron performed to determine the presence of hemosiderin is not a particularly sensitive test (Ghio, 2002), and (b) the observation of a liver hemangiosarcoma in $1 / 50$ without hemosiderin buildup is not inconsistent with the rate of incidence in historical controls, reported to be $0-6 \%$ (mean of $2.5 \%$ ) over all NTP studies of male mice (NTP, 2000b).

- What is the relation between Kupffer cell pigmentation and the sinusoidal endothelial cells, which demonstrate no pigmentation and from which the hemangiosarcomas arise? As discussed earlier, proposed mechanisms for DNA damage and increased synthesis do not necessarily involve the presence of iron within the endothelial cells. However, the observation of hemosiderin in the Kupffer cells through rather insensitive staining methods suggests that excess iron would be available to other, proximal cells such as the sinusoidal endothelial cells.

- If hemosiderin buildup in Kupffer cells is important for the development of EGBE-induced liver hemangiosarcomas, why was the incidence of this tumor not increased in the female mouse, for which hemosiderin pigmentation was at least as high as in the males? This observation is not unique to EGBE. In fact, all four NTP chemicals that induced early onset hemosiderin buildup in conjunction with an increased incidence of this tumor (EGBE, $p$-chloroaniline, $p$-nitroaniline, and pentachloroanisole) exhibited this apparent male specificity. Inherent differences between the antioxidant capacity of male versus female mice has been offered (Foster, 2000) as a possible explanation for the lack of a hepatic tumorigenic response in the latter. Though there is no direct evidence to support this hypothesis, the historical incidence of hemangiosarcomas does appear to be considerably higher in male versus female mice. NIH/NTP has observed liver hemangiosarcomas in 105 of the $4183(2.51 \%)$ male versus just 35 of the $4177(0.84 \%)$ female historical controls (NTP, 2000b; Klaunig, 2002). A more definitive answer to this question could come from additional research, perhaps involving measurement of the relative capabilities of the antioxidant systems of male and female mouse liver endothelial cells.

- Is the proposed relationship between the buildup of hemosiderin in Kupffer cells and the development of liver hemangiosarcomas supported by studies of other chemicals? NTP (2000a) reported that they did not find an association between hemosiderin deposition in the liver and liver neoplasms (adenomas, carcinomas, or hemangiosarcomas) in the 79 male and 103 female mice that had chemically related liver neoplasms at the end of an NTP study. However, a more focused review suggests that there may be a relationship between hemosiderin buildup in the Kupffer cells and liver hemangiosarcomas in male mice. All of the four chemicals observed by NTP to cause early onset (subchronic) hemosiderin buildup in male mice induced an increase in the incidence of liver hemangiosarcoma by the end of a 2-year NTP study (see Table 3).

- If hemosiderin deposition and increased hematopoietic cell proliferation can lead to tumor formation, why were no neoplasms noted in the spleen, where these effects were also observed? Foster (2000) suggests that cells of the spleen contain more active compensatory systems to protect against the harmful effects of iron buildup. This is not an unreasonable hypothesis in that cells of the spleen such as phagocytes do serve to rid the peripheral circulation of damaged red blood cells and would be expected to encounter high levels of hemoglobin and hemosiderin in the process, thereby requiring the need for greater protection against any harmful effects from such buildup. The fact that phagocytic cells of the spleen have a higher antioxidant capacity than sinusoidal endothelial cells lends some support to this hypothesis (DeLeve, 1998; Foster, 2000). Thus, the proposed mode of action is not necessarily inconsistent with the fact that hemosiderin buildup in splenic cells did not lead to the type of tumor formation observed in the liver, particularly given the very slight increase in liver tumor incidence observed.

\subsection{Other possible modes of action for liver hemangiosarcomas development in male mice}

The most recognized mechanism for the development of chemically induced liver hemangiosarcomas 
involves direct interaction with DNA (e.g., vinyl chloride). In vitro studies using rat and mouse hepatocytes (Park et al., 2002a) and Syrian Hamster embryo (SHE) cells (Park et al., 2002b) have also shown that EGBE and a primary metabolite, 2-butoxyacetic acid, do not directly induce oxidative damage, as measured by increased OH8dG and MDA and decreased Vitamin E levels at various exposure concentrations. In addition, EGBE does not appear to demonstrate the same pattern of effects as genotoxic compounds that cause liver hemangiosarcomas (Foster, 2000; Telles et al., 1979; Hong et al., 1980; Popper and Selikoff, 1981). However, given that butoxyacetaldehyde, a short-lived intermediate metabolite of EGBE, has been found to be significantly more active than either butoxyethanol or 2-butoxyacetic acid in mammalian cells in vitro (Elias et al., 1996), the possibility for interaction with DNA by metabolites of EGBE has not been completely ruled out.

\section{Relevance to humans}

\subsection{Forestomach papillomas and carcinoma observed in female mice}

It is clear that processes not relevant to humans at least contributed to the formation of these tumors, including consumption of bodily deposited EGBE, deposition and metabolism of EGBE in the mouse forestomach, and chronic irritation resulting from the long-term storage of EGBE and its metabolites in the forestomach. Incidences of ulcers consisting of a lesion in the forestomach wall that penetrated the full thickness of the forestomach epithelium were significantly increased in all exposed groups of females; and NTP (2000a) suggests that EGBE exposureinduced irritation caused inflammatory and hyperplastic effects in the forestomach and that "the neoplasia [papillomas and one carcinoma] was associated with a continuation of the injury/degeneration process". High concentrations of EGBE have been shown to sequester in the forestomachs of mice following gavage (Ghanayem et al., 1987a), inhalation (Green, 2000), and ip exposure (Poet et al., 2002). Due to the questionable relevance of these processes and the lack of a comparable organ in humans (an organ which is both histologically and functionally similar to the forestomach), the increased incidence of papillomas and carcinomas in the forestomach of chronically exposed high-dose female mice (NTP, 2000a) are not considered appropriate for use in the estimation of potential human cancer risk from EGBE exposure.

\subsection{Liver hemangiosarcomas in male mice}

If male mouse liver hemangiosarcomas are indeed secondary effects of hemolysis, like most other effects observed in rats and mice, they are not likely to be relevant to humans. Iron overload in humans either exposed to excess iron or genetically susceptible due to defects in iron metabolism has been associated with the induction of liver tumors (Mandishona et al., 1998; Stevens et al., 1994). However, humans are not likely to experience significant iron buildup from EGBE exposure because they are significantly less sensitive to the hemolytic toxicity of EGBE than rats and mice. Edmonson and Peters (1985) have suggested that focal necrosis of the liver observed in male rats following gavage administration of 250 and $500 \mathrm{mg}$ EGBE $/ \mathrm{kg}$ (Ghanayem et al., 1987b) was not consistent with typical anoxic centrilobular necrosis associated with anemia. However, no such effects have been reported in other animal studies or humans. Though effects in humans from chronic exposure to EGBE have not been studied, no hemolysis has been observed in controlled laboratory acute inhalation exposures of human volunteers to up to $195 \mathrm{ppm}$ EGBE (Carpenter et al., 1956), and only reversible hemolytic effects have been observed in humans acutely exposed to high oral doses of $400-1500 \mathrm{mg} / \mathrm{kg}$ EGBE (U.S. EPA, 1999a). Based on the results of in vitro testing, blood concentrations of the hemolytically active metabolite BAA must reach levels in human blood in excess of $7.5 \mathrm{mM}$ for even minimal prehemolytic changes to occur. This is 15 -fold higher than the blood level at which comparable effects occur in rats (Udden, 1995) and, according to the results of PBPK modeling, higher than maximum blood concentrations achievable from $6 \mathrm{~h}$ exposures of humans (whole body) to saturated atmospheres of EGBE (Corley et al., 1994).

In addition to the pharmacodynamic differences described above, there are also pharmacokinetic differences in the rodent and human response to EGBE ex- 


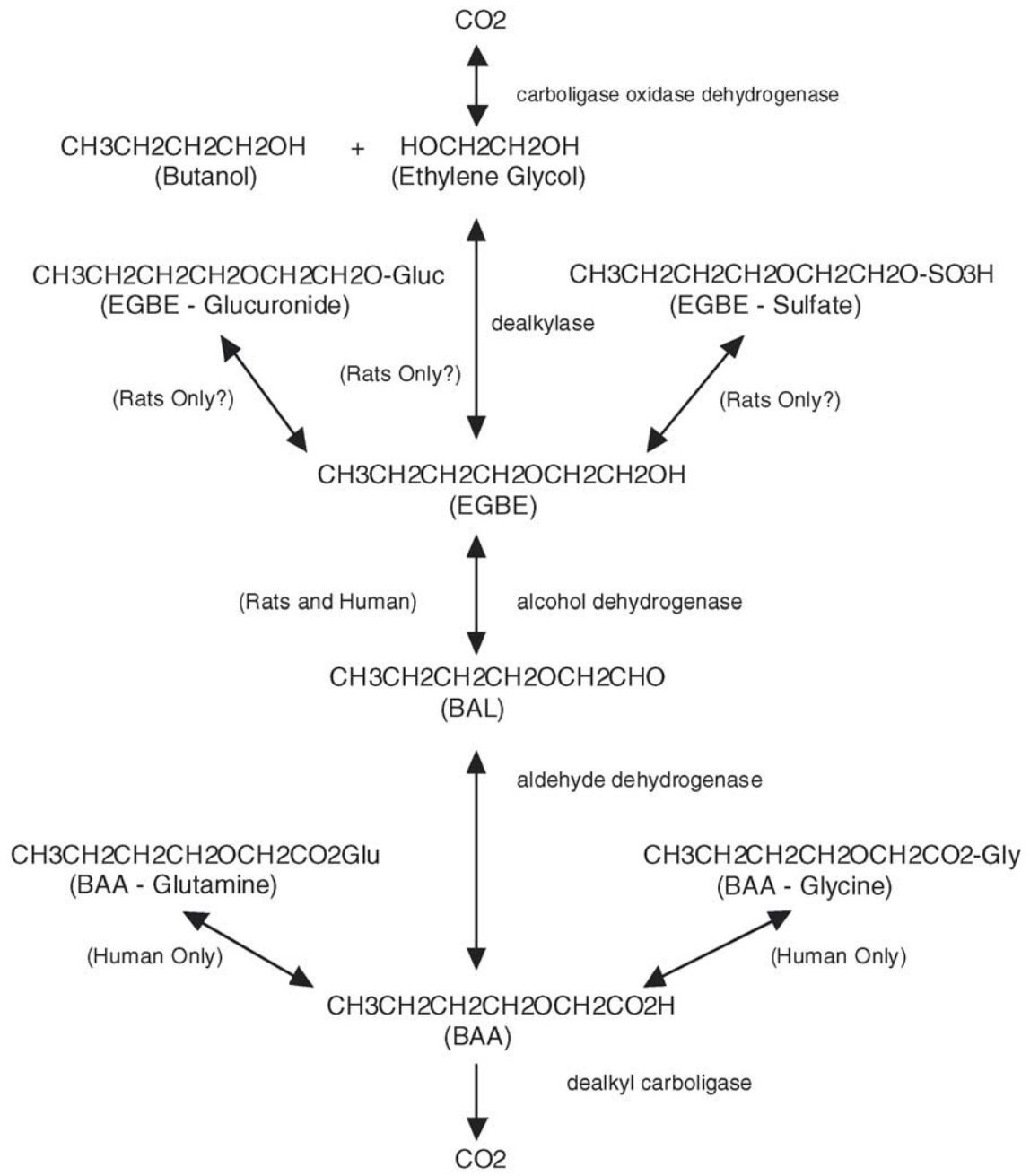

Fig. 2. Proposed Metabolic Scheme of EGBE in Rats and Humans (Adapted from Medinsky et al., 1990 and Corley et al., 1997).

posure (Fig. 2). The two main oxidative pathways of EGBE metabolism observed in rats are alcohol dehydrogenase $(\mathrm{ADH})$ and $O$-dealkylation by a cytochrome P450 dealkylase (CYP 2E1) (Medinsky et al., 1990). The former pathway, which involves the production of the toxic metabolite BAA, is applicable to both rats and humans. However, unlike rats, approximately twothirds of the BAA formed by humans is conjugated with glutamine and glycine (Corley et al., 1997; Rettenmeier et al., 1993). Thus, the glutamine and glycine detoxification pathways may provide humans with some measure of added protection from the harmful effects of BAA.

\subsection{Relevance to susceptible subpopulations, including children}

\subsubsection{Differences in susceptibility to hemolysis}

The primary noncancer effect of EGBE is hemolysis of red blood cells, which is caused by its primary metabolite, BAA. The possibility exists that certain human subpopulations with red blood cell walls less resistant to the lysis caused by BAA would be more sensitive to EGBE. However, Udden (1994) has shown that RBCs in normal and aged patients, and patients with sickle-cell anemia and hereditary spherocytosis, are all equally resistant to the hemolytic effects of BAA. 


\subsubsection{Metabolic differences}

Other potentially susceptible subpopulations include individuals with enhanced metabolism or decreased excretion of BAA. Older rats have been shown to have a reduced ability to metabolize the toxic metabolite BAA to $\mathrm{CO}_{2}$ and a diminished ability to excrete BAA in the urine (Ghanayem et al., 1987c, 1990). However, the relevance of this finding to the possible susceptibility of elderly humans is uncertain due to the fact that humans may have conjugation pathways for the excretion of BAA (BAA-glutamine and BAA-glycine) that are not available to the rat.

\subsubsection{Genetic differences}

Haufroid et al. (1997) conducted a human study on workers exposed to EGBE to test the possible influence of genetic polymorphism for CYP 2E1 on urinary BAA excretion rate. One exposed individual exhibited a mutant allele with increased cytochrome P450 oxidative activity that coincided with a very low urinary BAA excretion. However, the researchers did not measure BAA conjugated to glutamine, an alternative pathway for BAA excretion in humans. Further investigations on the influence of genetic polymorphism for CYP $2 \mathrm{E} 1$ on urinary BAA excretion rate are needed before any firm conclusions can be drawn.

\subsubsection{Gender differences}

Slight gender differences have been noted in rodent (Carpenter et al., 1956; Dodd et al., 1983; NTP, 1993b, 2000a), rabbit (Tyler, 1984), dog, monkey, and human studies (Carpenter et al., 1956), with females being consistently more susceptible to the primary hemolytic effects of EGBE. A number of secondary effects resulting from the hemolytic toxicity of EGBE, such as effects on the rat liver, kidneys, spleen, and bone marrow and, to a lesser extent, the thymus, are more pronounced in females (NTP, 1993b). In the process of studying and comparing the metabolic and cellular basis of EGBEinduced hemolysis, Ghanayem (1989) observed that blood from female human volunteers showed a slightly greater sensitivity to incubation with BAA than male blood.

\subsubsection{Age differences}

It is recognized that childhood exposures can be important determinants of certain cancers (Anderson et al., 2000), including early childhood bacterial infec- tions (Rowland and Drumm, 1998). Because a bacterial infection (Helicobacter hepaticus) has been associated with the development of liver hemangiosarcomas in mice (Nyska et al., 1997), it is not unreasonable to consider whether early childhood exposure to EGBE might be more important than adult exposures towards the formation of EGBE-induced liver hemangiosarcomas. However, it is generally recognized that children have fewer risk factors for anemia than adults (Berliner et al., 1995; Hord and Lukens, 1999), and Udden (2002) has shown that the red blood cells of children are no more sensitive to EGBE exposure than adult red blood cells. Thus, if the proposed mode of action for EGBE's involvement in the formation of these tumors in male mice is correct, there is no reason to believe that human children would be a susceptible subpopulation due to the fact that a significant buildup of iron from hemolysis would not be likely.

\section{Summary}

Since the publication of NTP's draft report (NTP, 1998a,b) on their 2-year inhalation bioassay of ethylene glycol butyl ether (EGBE; 2-butoxyethanol), there has been considerable debate among scientists from government, industry, and academia over EGBE's human carcinogenic potential. In 1999, EPA concluded that, while there was suggestive evidence from rodent studies, forestomach tumors in female mice and liver tumors in male mice, the human carcinogenicity of EGBE could not be determined (U.S. EPA, 1999a). Since that time, several research projects have been completed which shed considerable light on the mechanisms for the formation of these tumors. When this recently developed toxicological data for EGBE are reviewed under current draft EPA assessment guidelines (U.S. EPA, 1999a), the evidence suggests that the liver hemangiosarcomas in male mice and forestomach tumors in female mice observed following EGBE exposure developed via nonlinear modes of action and are of questionable relevance to humans. However, some uncertainty remains, particularly with respect to the specific mechanism of action for the formation of liver tumors in mice. In making an assessment regarding the relevance of liver hemangiosarcomas observed in mice to humans, EPA must consider uncertainties related to 
the following:

- the amount of iron sequestered by liver endothelial cells;

- the relative sensitivity of endothelial cells versus other liver cells;

- the reasons for the apparent sensitivity of male over female mice;

- the possibility of another mode of action (e.g., via mutagenic metabolites).

Given that humans lack an organ which is histologically or functionally similar to the forestomach and are insensitive to the hemolytic effects of EGBE, affirmation of the nonlinear modes of action discussed in this paper would almost certainly result in a determination that humans would not be expected to be susceptible to the forestomach and liver tumors observed in mice. An external peer review panel has reviewed recently completed toxicokinetic and genotoxicity research on EGBE and its metabolite $\mathrm{BAL}^{9}$ to determine whether the proposed nonlinear modes of action can be affirmed at this time. Until the results of this peer review have been assessed by the Agency, the existing IRIS determination (U.S. EPA, 1999a) that the human carcinogenicity of EGBE "cannot be determined at this time" applies.

\section{Appendix A. Questions and Answers Dr. Jeff Gift}

\section{Chair}

Dr. Gift's presentation is open for discussion. Questions?

\section{Question from Floor}

Why aren't there endothelial sarcomas in other tissues, why just the liver if it is going to act directly?

\section{Dr. Gift}

I think that is something that could stand additional research as to why endothelial cells in the liver are

\footnotetext{
9 Technical comments submitted to EGBE Docket (OAR-20030188) on 20 January 2004 by the American Chemistry Council in response to EPA's proposed rule to remove EGBE from the list of Hazardous Air Pollutants (68 FR 65648, 21 November 2003).
}

sensitive relative to other cells. You do get haemangiosarcomas in the spleen for instance, perhaps by other mechanisms. I think that perhaps there are protective mechanisms in the spleen that are better than protective mechanisms in the liver. I do not know for sure.

\section{Chair}

My recollection is that there were certainly haemangiosarcomas in other tissues, is that not right Rodney? They just were not significantly increased? Other questions? No? Thank you

\section{References}

Anderson, L.M., Diwan, B.A., Fear, N.T., Roman, E., 2000. Critical windows of exposure for children's health: cancer in human epidemiological studies and neoplasms in experimental animal models. Environ. Health Persp. 108 (Suppl. 3), 573594.

Bachowski, S., Kolaga, K.L., Xu, Y., Ketcham, C.A., Stevenson, D.E., Walborg Jr., E.F., Klaunig, J.E., 1997. Role of oxidative stress in the mechanism of dieldrin's hepatotoxicity. Ann. Clin. Lab. Sci. 27, 196-209.

Bennett, D., 2000. The distribution of radioactivity in the female B6C3f1 mouse following a single intravenous injection of 2butoxy[1-14c]ethanol. Report No. Ct1/r/1446. Central Toxicology Laboratory, Alderley Park, Macclesfield, Cheshire, UK.

Berliner, N., Duffy, T.P., Abelson, H.T., 1995. Approach to adult and child with anemia. In: Hoffman, R. (Ed.), Hematology: Basic Principles and Practice, 2nd ed. Churchill Livingstone, New York, NY, pp. 468-483.

Boatman, R.J., 2000. The significance of mouse liver hemangiosarcomas to the risk of cancer in man from exposures to ethylene glycol mono- $n$-butyl ether. Eastman Kodak Company, March 28.

Bogdanffy, M.S., Randall, H.W., Morgan, K.T., 1987. Biochemical quantitation and histochemical localization of carboxylesterase in the nasal passages of the Fischer-344 rat and B6C3F1 mouse. Toxicol. Appl. Pharmacol. 88, 183-194.

Bueld, J.E., Netter, K.J., 1993. Factors affecting the distribution of ingested propionic acid in the rat forestomach. Food Chem. Toxicol. 31, 169-176.

Carpenter, C.P., Pozzani, U.C., Wiel, C.S., Nair III, J.H., Keck, G.A., Smyth Jr., H.F., 1956. The toxicity of butyl cellosolve solvent. AMA Arch. Ind. Health 14, 114-131.

Commonwealth of Australia, 1996. 2-Butoxyethanol. Priority existing chemical number 6. Australian Government Publishing Service, Canberra. http://www.nicnas.gov.au/ publications/car/pec/pecindex.htm [January 27, 2003].

Corley, R.A., Bormett, G.A., Ghanayem, B.I., 1994. Physiologicallybased pharmacokinetics of 2-butoxyethanol and its major metabolite, 2-butoxyacetic acid, in rats and humans. Toxicol. Appl. Pharmacol. 129, 61-79. 
Corley, R.A., Markham, D.A., Banks, C., Delorme, P., Masterman, A., Houle, J.M., 1997. Physiologically-based pharmacokinetics and the dermal absorption of 2-butoxyethanol vapors by humans. Fundam. Appl. Toxicol. 39, 120-130.

Corley, R.A., Weitz, K.K., Mast, T.J., Miller, R.A., Thrall, B.D., 1999. Short-term studies to evaluate the dosimetry and modes of action of EGBE in B6C3F1 mice. Final Report. Battelle Project No. 29753.

DeLeve, L.D., 1998. Glutathione defence in non-parenchymal cells. Semin. Liver Dis. 18, 403-413.

Dodd, D.E., Snelling, W.M., Maronpot, R.R., Ballantyne, B., 1983. Ethylene glycol monobutyl ether: acute, 9-day, and 90-day vapor inhalation studies in Fischer 344 rats. Toxicol. Appl. Pharmacol. 68, 405-414.

Edmonson, H.A., Peters, R.L., 1985. Liver. In: Kissane, J.M. (Ed.), Anderson's Pathology, 8th ed. Mosby, St. Louis, MO, pp. 1096-1213.

Elias, Z., Daniere, M.C., Marande, A.M., Poirot, O., Terzelti, F., Schneider, O., 1996. Genotoxic and/or epigenetic effects of some glycol ethers: results of different short-term tests. Occup. Hyg. 2, 187-212.

Elliot, B.M., Ashby, J., 1997. Review of the genotoxicity of 2butoxyethanol. Mutat. Res. 387, 89-96.

Foster, J.R., 2000. EGBE (ethylene glycol butyl ether, EGBE): the proposed mode of action in the induction of hemangiosarcomas in male mouse liver and its significance for man. Report No. $\mathrm{Ctl} / \mathrm{r} / 1465$. Central Toxicology Laboratory, Alderley Park, Macclesfield, Cheshire, UK.

Frith, C.H., Ward, J.M., 1979. A morphologic classification of proliferative and neoplastic hepatic lesions in mice. J. Environ. Pathol. Toxicol. 3, 329-351.

Ghanayem, B.I., 1989. Metabolic and cellular basis of 2butoxyethanol-induced hemolytic anemia in rats and assessment of human risk in vitro. Biochem. Pharmacol. 38, 1679-1684.

Ghanayem, B.I., Burka, L.T., Sanders, J.M., Matthews, H.B., 1987a. Metabolism and disposition of ethylene glycol monobutyl ether (2-butoxyethanol) in rats. Drug Metab. Dispos. 15, 478-484.

Ghanayem, B.I., Burka, L.T., Matthews, H.B., 1987b. Metabolic basis of ethylene glycol monobutyl ether (2-butoxyethanol) toxicity: role of alcohol and aldehyde dehydrogenases. J. Pharmacol. Exp. Ther. 242, 222-231.

Ghanayem, B.I., Blair, P.C., Thompson, M.B., Maronpot, R.R., Matthews, H.B., 1987c. Effect of age on the toxicity and metabolism of ethylene glycol monobutyl ether (2butoxyethanol) in rats. Toxicol. Appl. Pharmacol. 91, 222-234.

Ghanayem, B.I., Sanders, J.M., Clark, A.M., Bailer, J., Matthews, H.B., 1990. Effects of dose, age, inhibition of metabolism and elimination on the toxicokinetics on the toxicokinetics of 2butoxyethanol and its metabolites. J. Pharmacol. Exp. Ther. 253, 136-143.

Ghanayem, B.I., Sullivan, C.A., 1993. Assessment of the hemolytic activity of 2-butoxyethanol and its major metabolite, butoxyacetic acid, in various mammals including humans. Hum. Exp. Toxicol. 12, 305-311.

Ghio, A., 2002. Personal communication. U.S. Environmental Protection Agency, National Health and Environmental Effects Research Laboratory, Research Triangle Park, NC.
Green, T., 1996. The metabolism of methyl methacrylate in the nasal tissues of rat and human. Zeneca/Central Toxicology Laboratory Report No. CTL/R/1290, issued December 4, 1996. Sponsor: CEFIC.

Green, T., 2000. The distribution of radioactivity in the female B6c3f1 mouse following a single 6 hour exposure to 2-butoxy[1$14 \mathrm{C}$ ]ethanol by inhalation. Report No. Ctl/r/1444. Central Toxicology Laboratory, Alderley Park, Macclesfield, Cheshire, UK, May.

Haseman, J.K., Hailey, J.R., Morris, R.W., 1998. Spontaneous neoplasm incidences in Fsicher 344 rats and B6C3F1 mice in twoyear carcinogenicity studies: a National Toxicology Program update. Toxicol. Pathol. 26 (3), 428-441.

Haufroid, V., Thirion, F., Mertens, P., Buchet, J.P., Lison, D., 1997. Biological monitoring of workers exposed to low levels of 2butoxyethanol. Int. Arch. Occup. Environ. Health 70, 232-236.

Hong, C.B., Winston, J.M., Lee, C.C., 1980. Hepatic angiosarcoma. Animal model: angiosarcoma of rats and mice induced by vinyl chloride. Am. J. Pathol. 101, 737-740.

Hord, J.D., Lukens, J.N., 1999. Anemias unique to infants and young children. In: Lee, R.G. (Ed.), Wintrobe's Clinical Hematology, vol. 2, 10th ed. Williams \& Wilkins, Baltimore, MD, pp. $1518-1537$.

Houglum, K., Ramm, G.A., Crawford, D.H., Witztum, J.L., Powell, L.W., Chojkier, M., 1997. Excess iron induces hepatic oxidative stress and transforming growth factor $\beta 1$ in genetic hemochromatosis. Hepatology 26, 605-610.

Junge, B., Carrion, Y., Bosco, C., Galleano, M., Puntarulo, S., Tapia, G., Videla, L., 2001. Effects of iron overload and lindane intoxication in relation to oxidative stress, Kupffer cell function, and liver injury in the rat. Toxicol. Appl. Pharmacol. 170, 23-28.

Kamendulis, L.M., Park, J.J., Klaunig, J.E., 1999. Potential mechanisms of rodent liver toxicity by EGBE: oxidative stress studies. Final Report to Ethylene Glycol Ethers Panel, Chemical Manufacturers Association, December. Indiana University, School of Medicine, Indianapolis, IN.

Klaunig, J.E., 2002. Mode of action of butoxyethanol for liver hemangiosarcomas in the male mouse. Presented to U.S. Environmental Protection Agency. National Center for Environmental Assessment, Washington, DC, December 3.

Klaunig, J.E., Xu, Y., Bachowski, S., Ketcham, C.A., Isenberg, J.S., Kolaja, K.L., Baker, T.K., Walborg Jr., E.F., Stevenson, D.E., 1995. Oxidative stress in non-genotoxic carcinogenesis. Toxicol. Lett. 82/83, 683-691.

Klaunig, J.E., Xu, Y., Isenberg, J.S., Bachowski, S., Kolaja, K.L., Jiang, J., Stevenson, D.E., Walborg Jr., E.F., 1998. The role of oxidative stress in chemical carcinogenesis. Environ. Health Persp. 106 (Suppl. 1), 289-295.

Krasavage, W.J., 1986. Subchronic oral toxicity of ethylene glycol monobutyl ether in male rats. Fundam. Appl. Toxicol. 6, 349-355.

Lesgards, J.F., Durand, P., Lassarre, M., Stocker, P., Lesgards, G., Lanteaume, A., Prost, M., Lehucher-Michel, M.P., 2002. Assessment of lifestyle effects on the overall antioxidant capacity of health subjects. Environ. Health Persp. 110, 479-486.

Mandishona, E., MacPhail, A.P., Gordeuk, V.R., Kedda, M.A., Paterson, A.C., Rouault, T.A., Kew, M.C., 1998. Dietary iron overload 
as a risk factor for hepatocellular carcinoma in Black Africans. Hepatology 27, 1563-1566.

Mattes, P.M., Mattes, W.B., 1992. Alpha-naphthyl butyrate carboxylesterase in human and rat nasal tissue. Toxicol. Appl. Pharmacol. 114, 71-76.

McConnell, E.E., Solleveld, H.A., Swenberg, J.A., Boorman, G.A., 1986. Guidelines for combining neoplasms for evaluation of rodent carcinogenesis studies. JNCI 76 (2), 283-289.

Medinsky, M.A., Singh, G., Bechtold, W.E., Bond, J.A., Sabourin, P.J., Birnbaum, L.S., Henderson, R.F., 1990. Disposition of three glycol ethers administered in drinking water to male F344/N rats. Toxicol. Appl. Pharmacol. 102, 443-455.

National Toxicology Program (NTP), 1993a. Toxicology and carcinogenesis studies of 1,3-butadiene (CAS no. 106-99-0) in B6C3F1 mice (inhalation studies). National Toxicology Program Technical Report Series No. TR-434. U.S. Department of Health and Human Services, National Institutes of Health, Washington, DC. http://www.ntp-server.niehs.nih.gov/htdocs/LTstudies/tr434.html.

National Toxicology Program (NTP), 1993b. Technical report on toxicity studies of ethylene glycol ethers 2-methoxyethanol, 2ethoxyethanol, 2-butoxyethanol administered in drinking water to F344/N rats and B6C3F1 mice. National Toxicology Program Toxicity Report no. 26, NIH Publication No. 93-3349. U.S. Department of Health and Human Services, National Institutes of Health, Washington, DC. Available from: NTIS, Springfield, VA.

National Toxicology Program (NTP), 1993c. Toxicology and carcinogenesis studies of pentachloroanisole (CAS no. 1825-214) in F344/N rats and B6C3F1 mice (gavage studies). National Toxicology Program Technical Report Series No. 414. U.S. Department of Health and Human Services, National Institutes of Health, Washington, DC.

National Toxicology Program (NTP), 1996. Toxicology and carcinogenesis studies of acetonitrile (CAS no. 75-05-8) in F344/N rats and B6C3F1 mice (inhalation studies). National Toxicology Program Technical Report Series No. TR447. U.S. Department of Health and Human Services, National Institutes of Health, Washington, DC. http://www.ntpserver.niehs.nih.gov/htdocs/LT-studies/tr447.html.

National Toxicology Program (NTP), 1998a. Toxicology and carcinogenesis studies of chloroprene (CAS no. 126-99-8) in $\mathrm{F} 344 / \mathrm{N}$ rats and $\mathrm{B} 6 \mathrm{C} 3 \mathrm{~F} 1$ mice (inhalation studies). National Toxicology Program Technical Report Series No. TR467. U.S. Department of Health and Human Services, National Institutes of Health, Washington, DC. http://www.ntpserver.niehs.nih.gov/htdocs/LT-studies/tr467.html.

National Toxicology Program (NTP), 1998b. Toxicology and carcinogenesis studies of 2-butoxyethanol (CAS no. 111-76-2) in F344/N rats and B6C3F1 mice (inhalation studies). National Toxicology Program Technical Report Series No. 484, NIH Draft Publication No. 98-3974. U.S. Department of Health and Human Services, National Institutes of Health, Washington, DC.

National Toxicology Program (NTP), 2000a. Toxicology and carcinogenesis studies of 2-butoxyethanol (CAS no. 111-76-2) in F344/N rats and B6C3F1 mice (inhalation studies). National Toxicology Program Technical Report Series No. 484. U.S. De- partment of Health and Human Services, National Institutes of Health, Washington, DC.

National Toxicology Program (NTP), 2000b. Toxicology data management system historical control tumor incidence summaries. http://www.ehpnet1.niehs.nih.gov/docs/ehpsearch.html.

National Toxicology Program (NTP), 2000c. Toxicology and carcinogenesis studies of methyleugenol (CAS no. 93-15-12) in F344/N rats and B6C3F1 mice (gavage studies). National Toxicology Program Technical Report Series No. 491. U.S. Department of Health and Human Services, National Institutes of Health, Washington, DC.

Nyska, A., Maronpot, R.R., Eldridge, S.R., Haseman, J.K., Hailey, J.R., 1997. Alteration in cell kinetics in control B6C3F1 mice infected with Helicobacter hepaticus. Toxicol. Pathol. 25, 591-596.

Park, J., Kamendulis, L.M., Klaunig, J.E., 2002a. Effects of 2butoxyethanol on hepatic oxidative damage. Toxicol. Lett. 126, 19-29.

Park, J., Kamendulis, L.M., Klaunig, J.E., 2002b. Mechanisms of 2-butoxyethanol carcinogenicity: studies on Syrian hamster embryo (SHE) cell transformation. Toxicol. Sci. 68, 4350 .

Poet, T.S., Soelberg, J.J., Curry, T.L., Studniski, K.G., Corley, R.A., 2002. In vivo kinetic studies with 2-butoxyethanol. Part 1. Target tissue dosimetry. Battelle Memorial Institute, Battelle Project No. 40974, Final Report (Draft) for the Ethylene Glycol Ethers Panel of the American Chemistry Council, Arlington, VA.

Poet, T.S., Soelberg, J.J., Weitz, K.K., Mast, T.J., Miller, R.A., Thrall, B.D., Corley, R.A., 2003. Mode of action and pharmacokinetic studies of 2-butoxyethanol in the mouse with an emphasis on forestomach dosimetry. Toxicol. Sci. 71 (2), 176-189.

Popper, H., Selikoff, I.J., 1981. Pathological lessons from vinyl chloride angiosarcoma. Am. J. Ind. Med. 2, 187-196.

Rettenmeier, A.W., Hennigs, R., Wodarz, R., 1993. Determination of butoxyacetic acid and $N$-butoxyacetylglutamine in urine of lacquerers exposed to 2-butoxyethanol. Int. Arch. Occup. Environ. Health 65 (Suppl. 1), S151-S153.

Rose, M.L., Germolec, D.R., Schoonhoven, R., Thurman, R.G., 1997. Kupffer cells are causally responsible for the mitogenic effect of peroxisome proliferators. Carcinogenesis 18, 1453-1456.

Rose, M.L., Rivera, C.A., Bradford, B.U., Graves, L.M., Cattley, R.C., Schoonhoven, R., Swenberg, J.A., Thurman, R.G., 1999. Kupffer cell oxidant production is central to the mechanism of peroxisome proliferators. Carcinogenesis 20, 27-33.

Rowland, M., Drumm, B., 1998. Clinical significance of Helicobacter infection in children. Brit. Med. Bull. 54, 95-103.

Siesky, A.M., Gottschling, B.C., Park, J., Kamendulis, L.M., Klaunig, J.E., 2001. Modulation of hepatic cell proliferation and oxidative stress in EGBE treated mice. Presented at the Society of Toxicology 40th Annual Meeting, San Francisco, CA, March.

Siesky, A.M., Kamendulis, L.M., Klaunig, J.E., 2002. Hepatic effects of 2-butoxyethanol in rodents. Toxicol. Sci. 70, 252-260.

Spolarics, Z., 1999. A carbohydrate-rich diet stimulates glucose-6phosphate dehydrogenase expression in rat hepatic sinusoidal endothelial cells. J. Nutr. 129, 105-108.

Stevens, R.G., Graubard, B.J., Micozzi, M.S., Neriishi, K., Blumberg, B.S., 1994. Moderate elevation of body iron level and in- 
creased risk of cancer occurrence and death. Int. J. Cancer 56, 364-369.

Telles, N.C., Thomas, L.B., Popper, H., Ishak, K.G., Falk, H., 1979. Evolution of thorotrast induced hepatic angiosarcomas. Environ. Res. 18, 74-87.

Tyler, T.R., 1984. Acute and subchronic toxicity of ethylene glycol monobutyl ether. Environ. Health Persp. 57, 185-191.

Udden, M.M., 1994. Hemolysis and decreased deformability of erythrocytes exposed to butoxyacetic acid, a metabolite of 2butoxyethanol. II. Resistance in red blood cells from humans with potential susceptibility. J. Appl. Toxicol. 14, 97-102.

Udden, M.M., 1995. Effects of butoxyacetic acid on human red cells. Occup. Hyg. 2, 283-292.

Udden, M.M., 2000. Rat erythrocyte morphological changes after gavage dosing with 2-butoxyethanol: a comparison with the in vitro effects of butoxyacetic acid on rat and human erythrocytes. J. Appl. Toxicol. 20, 381-387.

Udden, M.M., 2002. In vitro sub-hemolytic effects of butoxyethanol acid on human and rat erythrocytes. Toxicol. Sci. 69, 258264.

U.S. Environmental Protection Agency, 1986. Guidelines for carcinogen risk assessment. Federal Register 51, pp. 33992-34003.

U.S. Environmental Protection Agency, 1996. Proposed guidelines for carcinogen risk assessment. Report no. EPA/600/P92/003C. Office of Research and Development, Washington, DC. http://www.epa.gov/ORD/WebPubs/carcinogen/ [27 January, 2003].
U.S. Environmental Protection Agency, 1999a. Ethylene glycol monobutyl ether (EGBE) (2-butoxyethanol) (CASRN 111-762). Office of Health and Environmental Assessment, Environmental Criteria and Assessment Office, Cincinnati, $\mathrm{OH}$. http://www.epa.gov/iris/subst/0500.htm [27 January, 2003].

U.S. Environmental Protection Agency, 1999b. Guidelines for carcinogen risk assessment [draft]. Report No. NCEA-F-0644. Risk Assessment Forum, Washington, DC. http://www.epa.gov/ ncea/raf/pdfs/cancer_gls.pdf.

U.S. Environmental Protection Agency, 1999c. Acetonitrile (CASRN 75-08-8). Office of Health and Environmental Assessment, Environmental Criteria and Assessment Office, Cincinnati, OH. http://www.epa.gov/iris/subst/0205.htm [27 January, 2003].

Wang, Y.J., Ho, Y.S., Lo, M.J., Lin, J.K., 1995. Oxidative modification of DNA bases in rat liver and lung during chemical carcinogenesis and ageing. Chem.-Biol. Interact. 94, 135-145.

Xue, H., Kamendulis, L.M., Klaunig, J.E., 1999. A potential mechanism for 2-butoxyethanol (2-BE) induced mouse liver neoplasia. Toxicologist 48 (Suppl. 1), 231.

Yamaguchi, R., Hirano, T., Asami, S., Chung, M.H., Sugita, A., Kasai, H., 1996. Increased 8-hydroxyguanine levels in DNA and its repair activity in rat kidney after administration of a renal carcinogen, ferric nitrilotriacetate. Carcinogenesis 17, 2419-2422.

Ziouzenkova, O., Asatryan, L., Sevanian, A., 1999. Oxidative stress resulting from hemolysis and formation of catalytically active hemoglobin: protective strategies. Int. J. Clin. Pharmacol. Ther. $37,125-132$. 